\title{
Pressure Injury Risk Assessment and the Use of Intraoperative Polyurethane Foams to Prevent the Pressure Injuries
}

\author{
Anitawati Panggabean $^{1} \mathbb{D}$, Ariea Muliea ${ }^{1} \mathbb{D}$, Marisa Manik ${ }^{2 *}$ (D) Swingly Wikliv Dumanauw ${ }^{2}$ (D) \\ ${ }^{1}$ Siloam Hospitals Lippo Village, Tangerang, Indonesia; ${ }^{2}$ Faculty of Nursing, University of Pelita Harapan, Tangerang, Indonesia
}

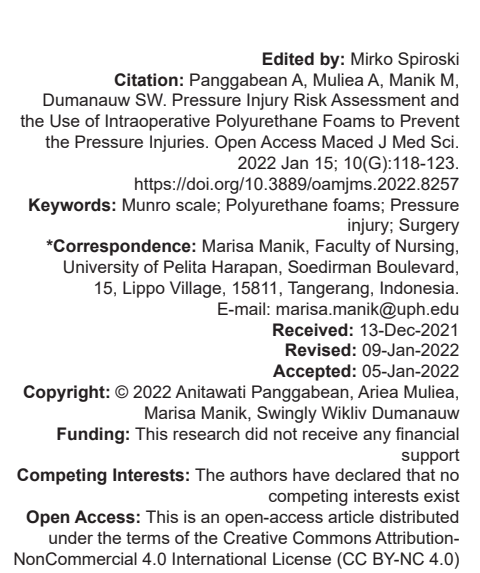

Introduction

A pressure injury is localized damage to the skin or underlying tissue because of pressure on a prominent bone (bony prominence) and external pressure over a long period [1] or may also be related to medical devices or other objects [2]. Direct stress disrupts blood flow resulting in tissue ischemia and eventually cell death. The risk factors for pressure injuries are classified into two groups. The first is the mechanical boundary conditions, including the magnitude and duration of the applied mechanical load and the mode of action, such as pressure or friction. The second factor is individual tolerance (internal anatomy including fine bone structure, tissue morphology, tissue mechanical properties, capacity, and active tissue transport called convection through metabolic processes in the bloodstream) [3].

Patients who will undergo surgery are one group of patients at risk of developing pressure sores. The incidence of pressure injuries in the operating room ranges from $4 \%$ to $45 \%$ [2]. Intraoperative pressure injuries occur when the load on the tissue is greater than the tissue tolerance or load during surgery up to
$72 \mathrm{~h}$ after surgery [4]. During the operation, the patient is immobilized, is positioned on a hard surface, cannot feel pain or discomfort due to pressure or friction, and cannot change position to relieve stress.

A systematic review reported that pressure sores in patients undergoing surgery increased from $0.3 \%$ to $57 \%$. A study in Brazil involving patients undergoing elective surgery found the incidence of pressure sores reaching $25 \%$ [5]. Studies suggest that $5-53.4 \%$ of hospital-acquired pressure ulcers are associated with prolonged or multiple surgical procedures [6]. The incidence of pressure sores in patients in the operating room of a private hospital in western Indonesia has increased from one case in 2018 to four cases in 2020.

Pressure injuries are associated with increased morbidity, hospitalization, and health care costs. In 2009 , hospital-acquired stress injuries accounted for \$11 billion/year in direct and indirect expenses [7]. A 2016 study found that these injuries increased hospital costs by $44 \%$ per hospital stay. Reported incidence rates vary with higher rates recorded in intensive care units and operating rooms. Patients who undergo surgery with a long duration have a higher risk for pressure sores in the hospital because of prolonged and unrelieved 
pressure on the skin. The length of the procedure or the type of surgery is a significant risk factor contributing to the incidence of pressure sores [7].

Prevention of pressure sores is essential in perioperative patients. Perioperative nurses must know risk factors and preventive measures to prevent pressure sores [8]. Prolonged surgery and anesthesia, specific positions for different operations, excessive blood loss, and physical maneuvers are substantial risk factors for the occurrence of intraoperative pressure sores in these patients. Based on this, appropriate intervention is needed to reduce the incidence of pressure sores during surgery [9]. Munro stated that using the Braden scale before surgery was ineffective because it only assessed moisture, immobilization, nutrition, and no intervention was carried out after the assessment [10]. The Munro Pressure Ulcer Risk Assessment Scale for Perioperative Patients is used to assess risk factors for developing pressure ulcers in patients. Assessment and risk scores are cumulative which include three stages, namely pre-, intra-, and post-operative [11].

One of the interventions to prevent intraoperative pressure sores is using polyurethane foam, which protects areas at risk of pressure sores during surgery. So far, in Indonesia, this intervention is still a collaborative intervention, and there is no operational standard for using the foam for patients with a moderate and high risk of pressure sores. Polyurethane foam is a polymer consisting of stiff and rigid organic units. Polyurethane foam is a flexible foam; after being given a load, it will return to its original shape. The foam molecules will push the air out of the foam cavity when under pressure so that the foam molecules will touch each other. When the pressure is released, the foam molecules will return to their original shape [12]. This study aimed to describe the risk of pre-operative pressure sores, the use of intraoperative polyurethane foam, and the incidence of post-operative pressure injuries in a private hospital in Indonesia.

\section{Methods}

This study used a cross-sectional descriptive quantitative design. The population was patients undergoing surgery at a private hospital in western Indonesia. The purposive sampling was used with inclusion criteria including patients with neurosurgery, cardiovascular, orthopedic, and laparotomy surgeries. The exclusion criteria were patients who had pressure sores before surgery. The number of samples obtained in this study from February to March 2021 was 81 respondents.

Data collection was carried out using four forms. First, the demographic form includes the medical record number, patient's initial, age, type of surgery, duration of the procedure, and patient position during the procedure. Second, the Munro scale assessment form. This study only used a Munro scale assessment form for the pre-operative phase to classify the risk level of pressure injury in the pre-operative phase (Table 1) and did not use the Munro scale assessment form for the intra- and post-operative phases.

The third form is the observation form for the use of intraoperative polyurethane foams. In this study, the polyurethanes foam size was adjusted according to the patient's position during surgery, and it was used during surgery. In the hospital where this study was conducted, the foam density was $24 \mathrm{~kg} / \mathrm{m}^{3}$ and a thickness of $5 \mathrm{~cm}$. The fourth form is an observation form to assess the presence or absence of pressure injuries 72 h postoperatively. The Cohen's Kappa test measured inter-rater reliability between observers before taking research data. The pre- and post-operative observers were one researcher with five assistant observers. The intraoperative observer was one researcher with three operating room nurses as assistant observers. Cohen's Kappa test shows a Kappa value of 1.0 with a significance value of 0.000 , indicating that the coefficient value suggests a correlation and that rater $A$ and rater $\mathrm{B}$ are mutually consistent.

This research has passed the ethical review of the Mochtar Riady Institute for Nanotechnology ethical committee with Protocol No. 2101004-04 and received permission from the hospital leader. The consent has been given to all respondents, including authorization to use the respondent's data for publication. Univariate analysis was used to analyze the data.

\section{Results}

Most of the respondents in this study were in the age group 60 years, as many as 39 people (48.1\%). Mainly the types of surgery performed were neurosurgery as many as 42 people $(51.9 \%)$ with a supine position as 51 people $(63 \%)$. The duration of the procedure ranged from 2 to $4 \mathrm{~h}$, namely 54 operations $(66.7 \%)$. The distribution of respondents' characteristics can be seen in Table 2.

Most respondents have a moderate risk of pressure sores, as many as 62 respondents $(76.5 \%)$ (Table 3$)$. The score was obtained from the accumulation of risk factors, including mobility, age, and comorbid factors (Table 4). The age factor was found as $19(30.6 \%)$ respondents are 40-59 years and $39(62.9 \%)$ respondents were in $\geq 60$ years of age. Respondents who required transfer assistance were 21 respondents $(33.9 \%)$, and five $(8.1 \%)$ respondents needed full assistance. Respondents with one type of comorbid as many as 29 (52.5\%) respondents, 
Table 1: Munro Pressure Ulcer Risk Assessment for Pre-operative Patients

\begin{tabular}{|c|c|c|c|c|}
\hline \multicolumn{5}{|c|}{ Pre-operative Risk Factors Score } \\
\hline Pre-operative Assessment & 1 & 2 & 3 & Total \\
\hline Mobility & Not limited, or slightly limited, moves independently & Very limited, requires transfer assistance & $\begin{array}{l}\text { Completely immobile, } \\
\text { requires full assistance }\end{array}$ & \\
\hline $\begin{array}{l}\text { Nutritional State (Length of } \\
\text { NPO status) }\end{array}$ & $12 \mathrm{~h}$ or $<$ & $>12 \mathrm{~h}$ but $<24 \mathrm{~h}$ & $>24 \mathrm{~h}$ & \\
\hline Body Mass Index (BMI) & $<035 \mathrm{~kg} / \mathrm{m}^{2}$ & $30-35 \mathrm{~kg} / \mathrm{m}^{2}$ & $>35 \mathrm{~kg} / \mathrm{m}^{2}$ & \\
\hline $\begin{array}{l}\text { Weight Loss (Weight loss in } \\
30-180 \text { days) }\end{array}$ & Up to $7.4 \%$ weight loss, no change or unknown & Between $7.5 \%$ to $9.9 \%$ weight loss & $\geq 00 \%$ weight loss & \\
\hline Age (Years) & 39 or less & $40-59$ & 60 or greater & \\
\hline Co-morbidity & $\begin{array}{l}\text { Each co-morbidity/grouping equals a score of } 1 \text {. A n } \\
\text { Smoking (current) } \\
\text { Prehypertension or high BP levels (BP>120/80 mm } \\
\text { Vascular/Renal/Cardio-vascular/Peripheral-vascular } \\
\text { Asthma/Pulmonary/Respiratory Disease } \\
\text { Prior History of Pressure Ulcer/Existing Pressure UI } \\
\text { Diabetes/IDDM }\end{array}$ & score of 0 and a maximum score of 6 is & & \\
\hline
\end{tabular}

Table 2: Distribution of Respondents' Characteristics Based on Age, Type of Surgery, Position during Surgery, and Length of Procedures $(n=81)$

\begin{tabular}{lll}
\hline Variable & Frequency $(\mathrm{n})$ & Percentage $(\%)$ \\
\hline Age & 15 & \\
$\leq 39$ years & 27 & 18,5 \\
$40-59$ years & 39 & 33,3 \\
$\geq 60$ years & 81 & 48,1 \\
$\quad$ Total & & 100 \\
Type of Surgery & 9 & \\
$\quad$ Cardio & 12 & 11.1 \\
$\quad$ Laparotomy & 42 & 14.8 \\
Neuro & 18 & 51.9 \\
Orthopedic & 81 & 22.2 \\
Total & & 100 \\
Position during Surgery & 11 & \\
Lateral & 19 & 13.6 \\
Prone & 51 & 23.5 \\
Supine & 81 & 63 \\
Total & & 100 \\
Length of Surgery & 2 & \\
$\leq 2 \mathrm{~h}$ & 54 & 2.5 \\
2-4 $\mathrm{h}$ & 25 & 66.7 \\
$\geq 4 \mathrm{~h}$ & 81 & 100 \\
Total & & \\
\hline
\end{tabular}

$11(18 \%)$ with two types of comorbid, and four $(1.65 \%)$ with three types of comorbid.

The data showed that 42 of 81 respondents used polyurethane foam, and 39 respondents did not use polyurethane foam during the intraoperative phase (Table 5). Most respondents with intraoperative polyurethane foam were aged 60 years. Intraoperative polyurethane foam was used mainly in neurosurgery type of surgery, $27(64.3 \%)$ respondents. There were $19(45.2 \%)$ respondents in the prone position, with most of the respondents or $23(54.8 \%)$ having a length of surgery in 2-4 h. Meanwhile, $28(71.8 \%)$ respondents who did not use polyurethane foam intraoperatively were at a moderate risk level for pressure ulcers.

Table 3: Distribution of Pressure Injury Risk in Pre-operative Patients Based on the Munro Scale Assessment $(n=81)$

\begin{tabular}{lll}
\hline Category of Risk & Frequency $(\mathrm{n})$ & Percentage $(\%)$ \\
\hline Low & 19 & 23.5 \\
Moderate & 62 & 76.5 \\
High & 0 & 0 \\
Total & 81 & 100 \\
\hline
\end{tabular}

The result showed that 42 respondents who used polyurethane foam during the intraoperative phase had no pressure injuries after $72 \mathrm{~h}$ post-operative, either in patients with low risk or moderate risk levels (Table 6). Similarly, 39 respondents who did not use polyurethane foam during the intraoperative phase showed no pressure injuries after $72 \mathrm{~h}$ postoperatively (Table 7).

Table 4: Distribution of Risk Factors of the Moderate Risk Category in the Pre-operative Phase $(n=62)$

\begin{tabular}{|c|c|c|c|}
\hline Risk Factors & Score & $\begin{array}{l}\text { Frequency } \\
\text { (n) }\end{array}$ & $\begin{array}{l}\text { Percentage } \\
(\%)\end{array}$ \\
\hline \multicolumn{4}{|l|}{ Mobility } \\
\hline Not limited, or slightly limited, moves independently & 1 & 36 & 58 \\
\hline Very limited, requires transfer assistance & 2 & 21 & 33.9 \\
\hline Completely immobile, requires full assistance & 3 & 5 & 8.1 \\
\hline Total & & 62 & 100 \\
\hline \multicolumn{4}{|l|}{ Nutritional state/Length of NPO status } \\
\hline$\leq 12 \mathrm{~h}$ & 1 & 62 & 100 \\
\hline $12-24 \mathrm{~h}$ & 2 & 0 & 0 \\
\hline$\geq 24 \mathrm{~h}$ & 3 & 0 & 0 \\
\hline Total & & 62 & 100 \\
\hline \multicolumn{4}{|l|}{ BMI (Body Mass Index) } \\
\hline$\leq 30 \mathrm{~kg} / \mathrm{m}^{2}$ & 1 & 62 & 100 \\
\hline $30-35 \mathrm{~kg} / \mathrm{m}^{2}$ & 2 & 0 & 0 \\
\hline$\geq 35 \mathrm{~kg} / \mathrm{m}^{2}$ & 3 & 0 & 0 \\
\hline Total & & 62 & 100 \\
\hline \multicolumn{4}{|l|}{ Weight loss in $30-180$ days } \\
\hline Up to $7.4 \%$ weight loss, no change or unknown & 1 & 62 & 100 \\
\hline Between $7.5 \%$ to $9.9 \%$ weight loss & 2 & 0 & 0 \\
\hline$\geq 10 \%$ weight loss & 3 & 0 & 0 \\
\hline Total & & 62 & 100 \\
\hline \multicolumn{4}{|l|}{ Age (years) } \\
\hline 39 or less & 1 & 4 & 6.5 \\
\hline $40-59$ & 2 & 19 & 30.6 \\
\hline$\geq 60$ & 3 & 39 & 62.9 \\
\hline Total & & 62 & 100 \\
\hline \multicolumn{4}{|l|}{ Co-morbidity } \\
\hline None & 0 & 18 & 27.9 \\
\hline 1 type of comorbid & 1 & 29 & 52.5 \\
\hline 2 types of comorbid & 2 & 11 & 18 \\
\hline 3 types of comorbid & 3 & 4 & 1.6 \\
\hline Total & & 62 & 100 \\
\hline
\end{tabular}

\section{Discussion}

As a person gets older, the risk of pressure sores increases because aging results in a decrease in lean body mass, muscle mass, and a reduced amount of water in the body, resulting in decreased skin elasticity. This condition results in a lack of tolerance of the skin surface to pressure. Based on the assessment from 81 respondents, it was found that most of the respondents, or $62.5 \%$ were 60 years old. A study conducted in Sweden found that $97 \%$ of patients aged 65 years had pressure sores, and $63 \%$ were over 80 years old [13]. The results showed that most of the types of surgery 
Table 5: Distribution of Intraoperative Polyurethane Foam Use based on Munro Scale Assessment in Pre-operative Phase ( $n=81)$

\begin{tabular}{|c|c|c|c|c|}
\hline \multirow[t]{3}{*}{ Risk factors } & \multicolumn{4}{|c|}{ Intraoperative Polyurethane Foam Use } \\
\hline & \multicolumn{2}{|l|}{ Yes $(n=42)$} & \multicolumn{2}{|l|}{ No $(n=39)$} \\
\hline & Frequency (n) & Percentage (\%) & Frequency (n) & Percentage (\%) \\
\hline \multicolumn{5}{|l|}{ Age (years) } \\
\hline$\leq 39$ & 6 & 14.3 & 9 & 23 \\
\hline $40-59$ & 14 & 33.3 & 13 & 33.3 \\
\hline$\geq 60$ & 22 & 52.4 & 17 & 43.6 \\
\hline Subtotal & 42 & 100 & 39 & 100 \\
\hline \multicolumn{5}{|l|}{ Type of surgery } \\
\hline Cardio & 8 & 19 & 1 & 2.6 \\
\hline Laparotomy & 1 & 2.4 & 11 & 28.2 \\
\hline Neuro & 27 & 64.3 & 15 & 38.5 \\
\hline Orthopedic & 6 & 14.3 & 12 & 30.8 \\
\hline Subtotal & 42 & 100 & 39 & 100 \\
\hline \multicolumn{5}{|c|}{ Position during surgery } \\
\hline Lateral & 9 & 21.4 & 2 & 5.1 \\
\hline Prone & 19 & 45.2 & 0 & 0 \\
\hline Supine & 14 & 33.3 & 37 & 94.9 \\
\hline Subtotal & 42 & 100 & 39 & 100 \\
\hline \multicolumn{5}{|c|}{ Length of surgery } \\
\hline$\leq 2 \mathrm{~h}$ & 2 & 4.8 & 0 & 0 \\
\hline $2-4 \mathrm{~h}$ & 23 & 54.8 & 31 & 79.5 \\
\hline$\geq 4 \mathrm{~h}$ & 17 & 40.5 & 8 & 20.5 \\
\hline Subtotal & 42 & 100 & 39 & 100 \\
\hline
\end{tabular}

performed were neurosurgery as many as $42(51.9 \%)$ respondents with a supine position as 51 (63\%). In the supine position, the areas at risk for pressure sores are the heels, sacrum, scapula, and back of the head [2]. Research conducted by Guo et al. revealed that the control group with the supine position during intraoperative had a significantly higher prevalence of pressure injuries [14]. The duration of the operation also affects the occurrence of pressure sores. In this study, most of the length of surgery was $2-4 \mathrm{~h}$, as many as $23(54.8 \%)$. It was found that the percentage of patients who had pressure sores increased with the increasing length of surgery; the prevalence occurring at a rate of $8.5 \%$ or higher among all patients undergoing surgical procedures that varied, but procedures that lasted more than $2.5-3 \mathrm{~h}$ were significantly more likely to cause skin and underlying tissue damage [15].

Table 6: Distribution of Pressure Injury at $72 \mathrm{~h}$ postoperatively in patients with intraoperative polyurethane foams $(n=42)$

\begin{tabular}{|c|c|c|c|c|c|c|}
\hline \multirow{3}{*}{$\begin{array}{l}\text { Pressure } \\
\text { Injury Risk } \\
\text { Category }\end{array}$} & \multirow{2}{*}{\multicolumn{2}{|c|}{$\begin{array}{l}\text { With Intraoperative } \\
\text { polyurethane foams }\end{array}$}} & \multicolumn{4}{|c|}{ Pressure Injury Incidence } \\
\hline & & & \multicolumn{2}{|l|}{ Yes } & \multicolumn{2}{|l|}{ No } \\
\hline & $\begin{array}{l}\text { Frequency } \\
\text { (n) }\end{array}$ & $\begin{array}{l}\text { Percentage } \\
(\%)\end{array}$ & $\begin{array}{l}\text { Frequency } \\
\text { (n) }\end{array}$ & $\begin{array}{l}\text { Percentage } \\
(\%)\end{array}$ & $\begin{array}{l}\text { Frequency } \\
\text { (n) }\end{array}$ & $\begin{array}{l}\text { Percentage } \\
(\%)\end{array}$ \\
\hline Low & 8 & $19 \%$ & 0 & $0 \%$ & 8 & 19 \\
\hline Moderate & 34 & $81 \%$ & 0 & $0 \%$ & 34 & 81 \\
\hline High & 0 & $0 \%$ & 0 & $0 \%$ & 0 & 0 \\
\hline Total & 42 & $100 \%$ & 0 & $0 \%$ & 42 & 100 \\
\hline
\end{tabular}

Most respondents of this study, or $62(76.5 \%)$, were at moderate risk for pressure injuries. The moderate risk level was obtained from risk factors including age 60 years, mobility factors, and comorbidities. Aging results in a decrease in lean body mass, muscle mass, and a reduced amount of water in the body. Skin elasticity decreases and results in a lack of tolerance of the skin's surface to pressure. A study conducted in a private hospital in Brazil found that advanced age was positively associated with perioperative pressure sores, with a higher incidence in patients aged 65 years at $40.0 \%$ [5].

Similarly, Powers and Ames found reduced movement or immobility is the most significant risk factor for pressure sores [8]. Other factors such as nutritional deficiencies and advanced age 60 years have increased the risk of pressure sores. Lenche et al. also found that from 2099 patients who were hospitalized; there were 1289 (61.4\%) patients with an average age of 76.32 years having a total pressure ulcer prevalence of $12.19 \%$, which was significantly affected by the presence of disease $(p=0.021)$ and neurological disorders $(p=0.051)$ [13]. Chiari et al. also stated that the patients most at risk for pressure ulcers were adults older than 80 years [16].

Table 7: Distribution of Pressure Injury at $72 \mathrm{~h}$ postoperatively in patients without intraoperative polyurethane foams $(n=39)$

\begin{tabular}{|c|c|c|c|c|c|c|}
\hline \multirow{3}{*}{$\begin{array}{l}\text { Pressure } \\
\text { Injury Risk } \\
\text { Category }\end{array}$} & \multirow{2}{*}{\multicolumn{2}{|c|}{$\begin{array}{l}\text { Without Intraoperative } \\
\text { polyurethane foams }\end{array}$}} & \multicolumn{4}{|c|}{ Pressure Injury Incidence } \\
\hline & & & \multicolumn{2}{|l|}{ Yes } & \multicolumn{2}{|l|}{ No } \\
\hline & $\begin{array}{l}\text { Frequency } \\
\text { (n) }\end{array}$ & $\begin{array}{l}\text { Percentage } \\
(\%)\end{array}$ & $\begin{array}{l}\text { Frequency } \\
\text { (n) }\end{array}$ & $\begin{array}{l}\text { Percentage } \\
(\%)\end{array}$ & $\begin{array}{l}\text { Frequency } \\
\text { (n) }\end{array}$ & $\begin{array}{l}\text { Percentage } \\
(\%)\end{array}$ \\
\hline Low & 11 & $28 \%$ & 0 & $0 \%$ & 11 & 28 \\
\hline Moderate & 28 & $72 \%$ & 0 & $0 \%$ & 28 & 72 \\
\hline High & 0 & $0 \%$ & 0 & $0 \%$ & 0 & 0 \\
\hline Total & 39 & $100 \%$ & 0 & $0 \%$ & 39 & 100 \\
\hline
\end{tabular}

Impaired mobility decreases a person's ability to change position, and prolonged pressure can result in tissue intolerance to ischemia [17]. A study showed a significant relationship between mobility ability and the degree of pressure sores in hospitalized patients [18]. Likewise, a study conducted by Powers and Ames found that the most significant risk factor for pressure sores is reduced movement or immobility [8]. Other factors such as nutritional deficiencies and advanced age 60 years have increased the risk of pressure sores. The study results are in line with a study conducted by Jaul et al. that old age, impaired mobility, and comorbidities can increase susceptibility to pressure sores because aging decreases dermal thickness and sensory perception, which can cause tissue injury more quickly [19]. Based on the results, 22 of 42 respondents with intraoperative polyurethane foam were elderly 60 years. Patients aged 60 years are at risk for pressure ulcers; therefore, using polyurethane foam can reduce the incidence of pressure sores [20]. There have been no specific studies related to the use of intraoperative foam in old age. Still, a study states that prophylactic dressings are bandages applied to the skin surface above the pressure point to reduce the forces of pressure, friction, and shear through a multiple layer construction, protecting the skin brittle from friction thereby preventing pressure injuries [2].

During the study, polyurethane foam was primarily used in neurosurgery with 27 (64.3\%) respondents and was in prone positions as many as $19(45.2 \%)$ respondents. Areas at risk for pressure sores in the prone position are the forehead, chin, cheeks, shoulder (anterior), elbow, chest (breast), genitalia, anterior pelvic bones, knee (patella), dorsal feet, and toes and nose [2]. Using polyurethane foam in the prone position intraoperatively will reduce the risk of pressure sores [21]. Most of the respondents who used polyurethane foam during this study were respondents with 2 to $4 \mathrm{~h}$ of surgery duration, which were $23(54.8 \%)$ respondents. An investigation revealed 
that the prevalence of pressure sores varies from $8.5 \%$ or higher among all patients undergoing surgical procedures. Still, procedures lasting more than 2.5 to $3 \mathrm{~h}$ are significantly more likely to cause skin and tissue damage underlying it [15]. According to Shen et al., the risk of pressure sores increases gradually with the lengthening of the operation [22]. It is impossible to reduce the length of the operation; therefore, a strategy that can prevent pressure sores in the intraoperative period is using polyurethane foams [23].

The results showed no pressure injury incidence after $72 \mathrm{~h}$ post-operative on respondents with and without intraoperative polyurethane foam. There was the probability of confounding factors in this study, such as pre-operative hemoglobin levels, albumin levels, lactate levels, intraoperative blood loss, postoperative immobilization, physical restraints, and postoperative care in the different units, for example, in the intensive care unit and general ward. The other factors include anesthesia, applied moisture, and bed type. Research by Poitras and Frey on the effectiveness of polyurethane foam dressings to prevent pressure sores showed a significantly lower incidence [20]. This study is in line with Huang et al., who analyzed dressings to prevent pressure ulcers and found that the incidence of pressure sores was less among those using foam compared to standard routine care [24]. Primiano stated that when a surgical patient develops a pressure ulcer within $72 \mathrm{~h}$ of the procedure, it likely indicates that the wound results from surgery [15]. The rate of intraoperative pressure ulcers ranges from $12 \%$ to $66 \%$ in surgical patients; it is caused by strong or prolonged pressure that does not subside for a long time, resulting in damage to the skin and underlying tissue. European Pressure Ulcer Advisory Panel suggested that film dressings can help protect the skin from the adverse effects of friction [2]. In addition, they indicated that foam pads could protect body parts from the risk of shear injury. The material that seems to be most effective overall is polyurethane foam, especially in multi-layers. The results showed that 39 respondents who did not use intraoperative polyurethane foam, both with low and moderate risk levels, did not have pressure injuries until $72 \mathrm{~h}$ of post-operative observation. This result needs further analysis related to other factors such as confounding factors during the intraoperative phase and post-operative care.

There are several study limitations, including the setting was only in one hospital, with a descriptive approach that did not give a cause and effect relationship. Respondent in the study was voluntary, and the sample selection was intentional and not random. Despite these limitations, this study has provided valuable data regarding the use of Munro scale assessment to help nurses identify the risk level of pressure injury and positive insight for applying polyurethane foam as a strategy to prevent pressure ulcers. Further research is needed on the effectiveness of using polyurethane foam during the intraoperative phase in a more significant number of respondents with different research methodologies.

\section{Conclusion}

The results of this study emphasize information that the Munro scale assessment can help predict the level of risk of pressure injuries in patients undergoing surgery. It is expected that hospitals will consistently apply standard pre-operative procedures to improve the quality of care for patients undergoing surgery. The role of nurses is enormous in the prevention of pressure sores. Nurses are expected to be consistent and responsible in identifying patients at risk for pressure injuries and strengthen collaboration with surgeons in implementing pressure ulcer prevention strategies during the intraoperative phase.

\section{References}

1. Smith S, Snyder A, McMahon L Jr., Petersen L, Meddings J. Success in hospital-acquired pressure ulcer prevention: A tale in two data sets. Health Aff (Millwood). 2018;37(11):1787-96. https://doi.org/10.1377/hlthaff.2018.0712

PMid:30395514

2. European Pressure Ulcer Advisory Panel, National Pressure Injury Advisory Panel, and Pan Pacific Pressure Injury Alliance. Prevention and Treatment of Pressure Ulcers/Injuries: Clinical Practice Guideline; 2019.

3. Coleman S, Nixon J, Keen J, Wilson L, McGinnis E, Dealey C, et al. A new pressure ulcer conceptual framework. J Adv Nurs. 2014;70(10):2222-34. https://doi.org/10.1111/jan.12405 PMid:24684197

4. McKenzie RJ, Ramirez C. Preventing Pressure Injuries in the Operating Room. In: Pressure Injuries: Prevention Across the Acute-care Continuum; 2018. Available from: https://americannursetoday.mydigitalpublication.com/ publication/?m=41491\&i=492685\&p=1\&ver=html5. [Last accessed on $2021 \mathrm{Jul} 12]$

5. Peixoto CA, Ferreira MB, Felix MM, Pires P, Barichello E, Barbosa $\mathrm{MH}$. Risk assessment for perioperative pressure injuries. Rev Latin Am Enferm. 2019;27:e3117. https://doi. org/10.1590/1518-8345.2677-3117

PMid:30698218

6. Kirkland-Walsh $\mathrm{H}$, Teleten $\mathrm{O}$, Wilson $\mathrm{M}$, Raingruber $\mathrm{B}$. Pressure mapping comparison of four OR surfaces. AORN J. 2015;102(1):61.e1-619. https://dx.doi.org/10.1016\%2Fj. aorn.2015.05.012

PMid:26119617

7. Joseph J, McLaughlin D, Darian V, Hayes L, SiddiquiA. Alternating pressure overlay for prevention of intraoperative pressure injury. J Wound Ostomy Continence Nurs. 2019;46(1):13-7. https://doi. org/10.1097/WON.0000000000000497

PMid:30601427 
8. Powers J, Ames C. Take Action to Solve Causes of Pressure Injuries. In: Pressure Injuries: Prevention Across the Acute-care Continuum; 2018. Available from: https://americannursetoday.mydigitalpublication.com/ publication/?m=41491\&i=492685\&p=1\&ver=html5. [Last accessed on $2021 \mathrm{Jul}$ 12].

9. Gao L, Yang L, Li X, Chen J, Du J, Yang H. Risk factors for intraoperative pressure ulcers in surgical patients. Int $\mathrm{J}$ Clin Exp Med. 2018;11(7):7429-35. http://www.ijcem.com/files/ ijcem0075226.pdf PMid:30375697

10. Munro AC. The development of a pressure ulcer risk-assessment scale for perioperative patients. AORN J. 2010;92(3):272-87. https://doi.org/10.1016/j.aorn.2009.09.035

PMid:20816101

11. Li D, Tang J, Gan X. Reliability and validity of the Munro scale on the assessment of pressure ulcer risks in adult perioperative patients: A cross-sectional study. Int J Clin Exp Med. 2018;11(9):9811-8. http://www.ijcem.com/files/ijcem0065427.pdf

12. The Polyurethane Foam Association. Viscoelastic (Memory) Foam. Tennessee: The Polyurethane Foam Association; 2016. In-Touch. Available from: https://www.pfa.org/wp-content/ uploads/2019/02/InTouch_v11.1.pdf. [Last accessed on 2021 Jul 12].

13. Lenche N, Katerina D, Nikolchev A, Lidija P, Biljana PZ, Milenko $K$. The influence of comorbidity on the prevalence of pressure ulcers in geriatric patients. Glob Dermatol. 2016;3(3):319-22. https://doi.org/10.15761/god.1000183

14. Guo Y, Zhao K, Zhao T, Li Y, Yu Y, Kuang W. The effectiveness of curvilinear supine position on the incidence of pressure injuries and interface pressure among surgical patients. J Tissue Viability. 2019;28(2):81-6. https://doi.org/10.1016/j. jtv.2019.02.005

PMid:30878174

15. Primiano M, Friend M, McClure C, Nardi S, Fix L, Schafer M, et al. Pressure ulcer prevalence and risk factors among prolonged surgical procedures in the OR. AORN J. 2015;94(6):555-6. https://doi.org/10.1016/j.aorn.2011.03.014

PMid:22118201

16. Chiari P, Forni C, Guberti M. Predictive factors for pressure ulcers in an older adult population hospitalized for hip fractures: A prognostic cohort study. PLoS One. 2017;12(1):e0169909. https://doi.org/10.1371/journal.pone.0169909

PMid:28068425

17. Kirman NC. Pressure Injuries (Pressure Ulcers) and Wound Care; 2020. Available from: https://emedicine.medscape.com/ article/190115-overview. [Last accessed on 2021 Jul 12].

18. Riyadi ME, Hanafi Al, Arningsih NK. Mobility ability and the degree of pressure sores in hospitalized patients. Health Sci Pharm J. 2020;4(1):28. https://doi.org/10.32504/hspj.v4i1.177

19. Jaul E, Barron J, Rosenzweig JP, Menczel J. An overview of co-morbidities and the development of pressure ulcers among older adults. BMC Geriatr. 2018;18(1):305. https://doi. org/10.1186/s12877-018-0997-7 PMid:30537947

20. Poitras V, Frey N. Polyurethane Foams Dressing for the Prevention Pressure Ulcers: Clinical and Cost-effectiveness and Guidelines. Ottawa (ON): Canadian Agency for Drugs and Technologies in Health; 2017. Available from: https:// europepmc.org/article/nbk/nbk470692. [Last accessed on 2021 Jul 12].

21. Yang YT, Shin HS. Effect of Soft Silicone Foams Dressings on Intraoperatively Acquired Pressure Injuries: A Randomized Study in Patients Undergoing Spinal Surgery. NIH; 2017.

22. Shen $W Q$, Chen $H L, X u Y H$. The relationship between length of surgery and the incidence of pressure ulcers in cardiovascular surgical patients: A retrospective study. Wound Care J. 2015;28(10):444-50. https://doi.org/10.1097/01. ASW.0000466365.90534.b0 PMid:26375947

23. Bulfone G, Marzoli I, Quattri R. A longitudinal study of the incidence of pressure sores and the associated risks and strategies adopted in Italian operating theatres. J Perioper Pract. 2012;22(2):50-6. https://doi.org/10.1177/175045891202200202 PMid:22724304

24. Huang L, Woo KY, Liu L, Wen R, Hu A, Shi C. Dressing for preventing pressure ulcers: A meta-analysis. Adv Skin Wound Care. 2015;28(6):267-73. https://doi.org/10.1097/01. ASW.0000463905.69998.0d

PMid:25988736 